\title{
REVISED Evaluation of hearing level in patients on long term
}

\section{aspirin therapy [version 2; peer review: 1 approved, 2}

\section{approved with reservations]}

\author{
Apar Pokharel(D), Sangita Bhandary
}

ENT Department, College of Medical Sciences, Bharatpur, Chitwan, Nepal

V2 First published: 07 Apr 2017, 6:445

https://doi.org/10.12688/f1000research.11131.1

Latest published: 16 Feb 2018, 6:445

https://doi.org/10.12688/f1000research.11131.2

\section{Abstract}

Introduction: Aspirin is a routinely prescribed drug, most notably for cardiovascular diseases, such as myocardial ischemia. This cross sectional, comparative study study aims to explore differences in hearing status between the cardiovascular disease patients on aspirin therapy and age matched controls.

Methods: The study population consisted of 182 patients with heart disease taking long term aspirin (i.e., for more than one year). The control population consisted of 221 age matched controls who were not taking aspirin.

Results: It was found that age of patient, not aspirin intake, was more important risk factor contributing to hearing loss.

Conclusions: When confounding factors like age of the patient, hypertension and diabetes were taken into account, aspirin in its antiplatelet dose was not found to be the cause of any audiological problems like tinnitus and hearing loss.

Keywords

aspirin, sensorineural hearing loss, cardiovascular diseases

\section{Open Peer Review \\ Approval Status ? ? \\ 12 \\ 23 \\ version 2 \\ (revision) \\ 16 Feb 2018 \\ version 1 \\ 07 Apr 2017

$?$ \\ ? \\ $?$ \\ view}

1. Adam M. Sheppard, State University of New York at Buffalo, Buffalo, USA

2. Elsdon Storey, Monash University, Melbourne, Australia

3. Ajoy Mathew Varghese (iD), Christian Medical College, Vellore, India

Sheeja Susan John, Christian Medical College, Vellore, India

Any reports and responses or comments on the article can be found at the end of the article. 
Corresponding author: Apar Pokharel (apar.pokharel@gmail.com)

Author roles: Pokharel A: Data Curation, Formal Analysis, Funding Acquisition, Investigation, Methodology, Resources, Software, Visualization, Writing - Original Draft Preparation, Writing - Review \& Editing; Bhandary S: Conceptualization, Project Administration, Supervision, Validation, Visualization

Competing interests: No competing interests were disclosed.

Grant information: The author(s) declared that no grants were involved in supporting this work.

Copyright: $\odot 2018$ Pokharel A and Bhandary S. This is an open access article distributed under the terms of the Creative Commons Attribution License, which permits unrestricted use, distribution, and reproduction in any medium, provided the original work is properly cited. Data associated with the article are available under the terms of the Creative Commons Zero "No rights reserved" data waiver (CCO 1.0 Public domain dedication).

How to cite this article: Pokharel A and Bhandary S. Evaluation of hearing level in patients on long term aspirin therapy [version 2; peer review: 1 approved, 2 approved with reservations] F1000Research 2018, 6:445 https://doi.org/10.12688/f1000research.11131.2

First published: 07 Apr 2017, 6:445 https://doi.org/10.12688/f1000research.11131.1 


\section{REVISED Amendments from Version 1}

As per my article reviewer suggestions, I have made necessary corrections. I have added one table in the article comparing the severity of hearing loss of study population and controls. I have also uploaded two tables (Supplementary File 1 and Supplementary File 2) with air conduction and bone conduction thresholds of studied population in different frequencies.

See referee reports

\section{Introduction}

The great industrial and technological revolutions of the past two centuries have resulted in changes in the causes of illnesses and death. Infections and malnutrition were the most common cause of death before 1900. Because of improved nutrition and public health measures in the developed countries, the greatest cause of morbidity has been cardiovascular disease (CVD) and cancer. As lifestyle changes have also been observed in developing countries, morbidity and mortality rates due to cardiovascular conditions are also becoming more common in these countries. This is known as the epidemiological transition because this shift is highly correlated with changes in personal and collective wealth (the economic transition), social structure (the social transition) and demographics (the demographic transition) ${ }^{1}$.

Aspirin is a routinely prescribed drugs, most notably for cardiovascular diseases such as, myocardial ischemia. Myocardial ischemia or ischemic heart disease (IHD) is a disease where there is a decreased blood supply to the heart muscle due to coronary artery disease $(\mathrm{CAD})^{2}$. The ototoxic effects of high doses (several grams per day) of salicylates, reversible hearing loss and tinnitus, are well documented ${ }^{3}$.

No studies have been done in the past to assess hearing loss in patients with cardiovascular diseases on aspirin therapy in Nepal. The present study was done to explore the differences in hearing status between patients with cardiovascular disease on aspirin therapy and age matched controls. It also aims to analyze correlation of hearing loss with the age of patients and presence of co-morbid illnesses.

\section{Methods}

The study was conducted in the department of Otorhinolaryngology and Head \& Neck Surgery, BPKIHS, Dharan. The duration of the study was one year (from $1^{\text {st }}$ Feb, 2011 to $1^{\text {st }}$ Feb, 2012). This was a cross sectional comparative study.

The study population consisted of cases of patients with heart disease taking long term aspirin (i.e., for more than one year). They were informed about the design and purpose of the study and requested to visit the ear, nose and throat outpatient department (ENT OPD) voluntarily to take part in the study. The control population consisted of age matched controls who were not taking aspirin. No major, active interventions were carried out other than those routinely required for diagnosis. Ethical approval was obtained from the institutional ethical review board of B.P. Koirala Institute of Health Sciences (87/2070/071). Written informed consent was obtained from both study and control populations prior to the study. The current study did not involve any invasive procedure and did not cause any physical or mental harm to the patients. No other interventions were carried out. There was no financial burden to the patients during study. The inclusion criteria was patients of age group 15-75 years who were taking aspirin for heart disease. The exclusion criteria was patients with hearing loss after trauma i.e. after explosion, head injury, ear trauma, or perforation of tympanic membrane, and patients with positive family history of hearing loss, or with CNS disease.

All study participants visited ENT OPD so that their clinical history could be assessed according to the proforma and so that they could undergo clinical and otological examination. General physical examination and detailed otological examination of ear, nose and throat was carried out according to proforma to exclude middle ear pathology and conductive hearing loss. All the study participants had normal ears during ear examinations. The Heine Mini 3000 otoscope was used in all cases for the examination of the external auditory canal and the tympanic membrane.

The study population was asked about regular use of aspirin which was defined as daily intake of $75 \mathrm{mg}^{4}$. The study population was interviewed regarding hearing loss and tinnitus and any past history of ear disease was excluded. Tinnitus is a recurrent ringing, roaring or buzzing sensation lasting for five minutes or longer ${ }^{5}$.

Complete birth and developmental history was taken to exclude congenital and other causes of acquired hearing loss. Detailed drug history was taken, looking especially for ototoxic drugs. Past history of ear trauma and head injury was noted to rule out prior hearing loss. Systemic causes of hearing loss e.g. Diabetes mellitus, hypertension, and chronic kidney disease, should also be noted. The diagnosis of diabetes mellitus, hypertension and chronic kidney disease were made based on the previous medical records of study population and controls.

Tuning fork tests (Rinne's, Weber's) were carried out with 256, 512, $1024 \mathrm{~Hz}$ tuning fork. Lower frequency fork e.g. 128 was not used because of difficulty in interpretation. Rinne and Weber tests were done to find the better hearing cochlea. Each participant underwent a hearing test by pure tone audiometry (PTA) in a sound-proof room. The Madsen Electronics Orbiter 922 Version 2 clinical audiometer was chosen for the study, and tests were performed by a trained audiometrician. The audiometric testing was done by a single person to ensure test-retest reliability. The extent of hearing loss was determined in all subjects. An average of two pure tone responses was calculated in cases of doubt. The results were documented as low (250-500 Hz), middle $(1000-2000 \mathrm{KHz})$, and high $(4000-8000 \mathrm{~Hz})$. The value of the worst ear was taken when there was slight difference in the hearing loss value between the two ears. Hearing thresholds of the study group were compared with those of control group. All findings were noted and categorized on the basis of a proforma data collection sheet. A graph was plotted with the PTA findings. The data were entered in Excel and analysis was carried out using SPSS version 16.0. The Chi-squared test was done to compare hearing loss between case and control, across different age groups and at different durations of intake of aspirin. 


\section{Results}

The study population consisted of 182 patients with heart disease taking long term aspirin (i.e., for more than one year). The control population consisted of 221 age matched healthy controls who were not taking aspirin. $45.3 \%$ of the study population were male and $54.7 \%$ were female. Among controls, $48.1 \%$ of the cases were male and $51.9 \%$ of the cases were female (Table 1).

Table 1. Demographic Data.

\begin{tabular}{|l|l|l|l|}
\hline Age & Less than 50 yrs & $\begin{array}{l}\text { Study } \\
\text { Population }\end{array}$ & $\begin{array}{l}\text { Control } \\
\text { Population }\end{array}$ \\
\hline & $20.9 \%$ & $21.7 \%$ \\
\hline \multirow{2}{*}{ Se-59 yrs } & $31.3 \%$ & $29.7 \%$ \\
\hline \multirow{2}{*}{ Ro-75 yrs } & $47.6 \%$ & $48.4 \%$ \\
\hline & Male & $45.3 \%$ & $48.1 \%$ \\
\hline & Female & $54.7 \%$ & $51.9 \%$ \\
\hline & Indo-Aryans & $64.3 \%$ & $60.1 \%$ \\
\hline & East-Asians & $35.7 \%$ & $39.9 \%$ \\
\hline
\end{tabular}

Both study and control populations were categorized into three groups according to age. The first group ranged between 15-50 years of age, the second 51-59 and the third, 60-75. The mean age was 63.7 years for the study population and 64.2 years for controls. $47.6 \%$ of the study population was in the $60-75$ year age group; in the control group the number of participants in the 60-75 age group which was higher, with $48.4 \%$ (Table 1).

$64.3 \%$ of the study population were of Indo-Aryan origin and $35.7 \%$ were of East Asian origin. Among the controls, 60.1\% were of Indo-Aryan origin and $39.9 \%$ were of East Asian origin (Table 1).

The occupation of participants was more or less equally distributed, with housewives dominating in both cases and controls. Careful history was taken to rule out noise induced hearing loss in each occupation as seen in Figure 1.

Out of 182 study population, only 115 presented with tinnitus. Among 221 controls, 124 presented with tinnitus. The result was statistically insignificant as in Figure 2.

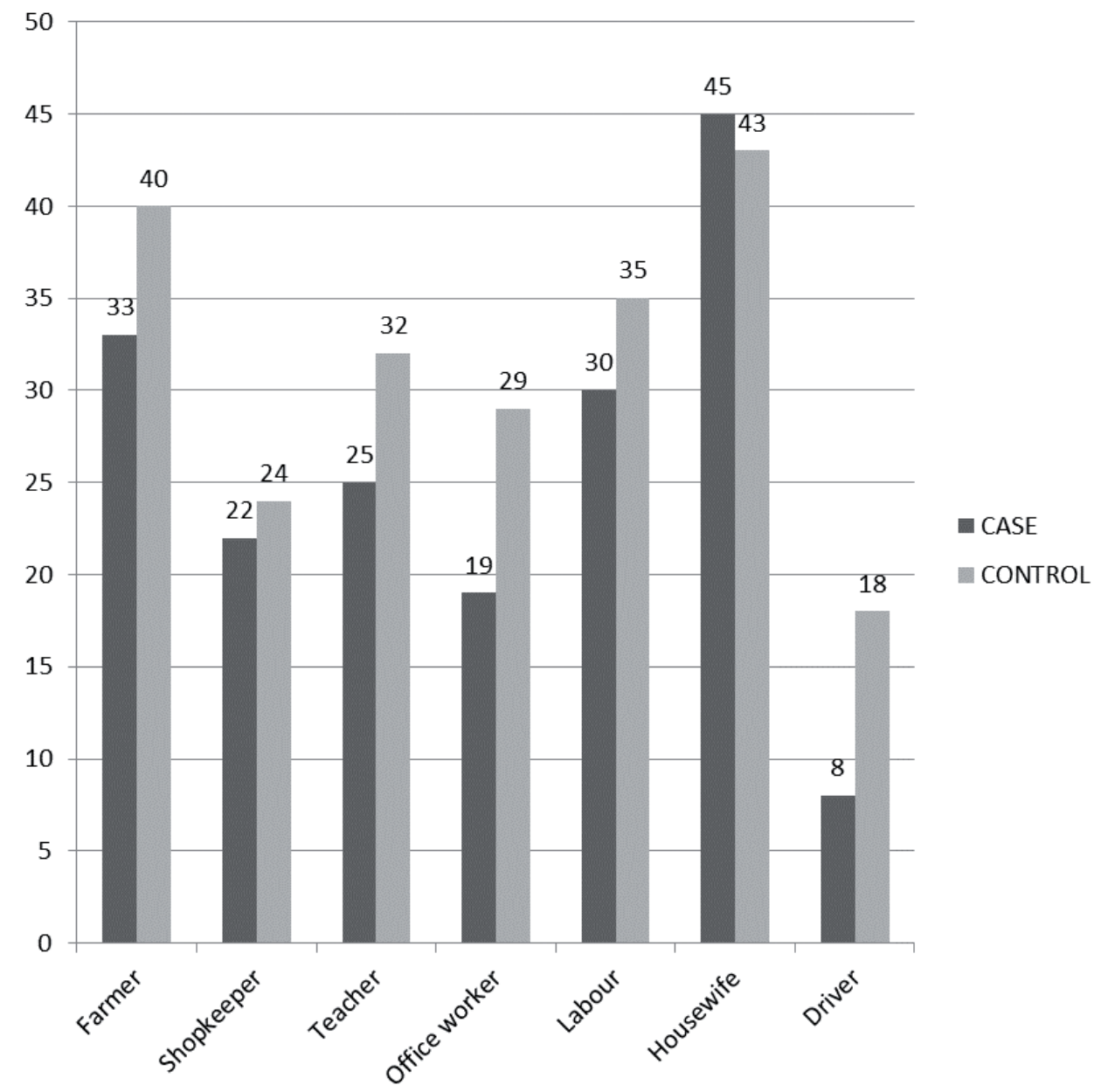

Figure 1. Occupation distribution between cases and controls (182 cases and 221 controls). 
Out of 182 study population, only 120 presented with sensorineural hearing loss (SNHL). Among 221 controls, 126 presented with SNHL. The result was not statistically significant $(p$ value $=0.68)$ implying that aspirin was not the cause of hearing loss in study population as seen in Figure 3.

As seen in Figure 4, maximum percentage of both the study population and controls have normal hearing. Around $24 \%$ of both study population and controls have moderate hearing loss as per WHO criteria.

The data obtained from bivariate analysis was followed by binary logistic regression analysis with backward conditional method using SPSS version 16.0 in order to adjust and explore the significance of explanatory variables. Hearing loss was considered the dependent variable. The independent variables which had

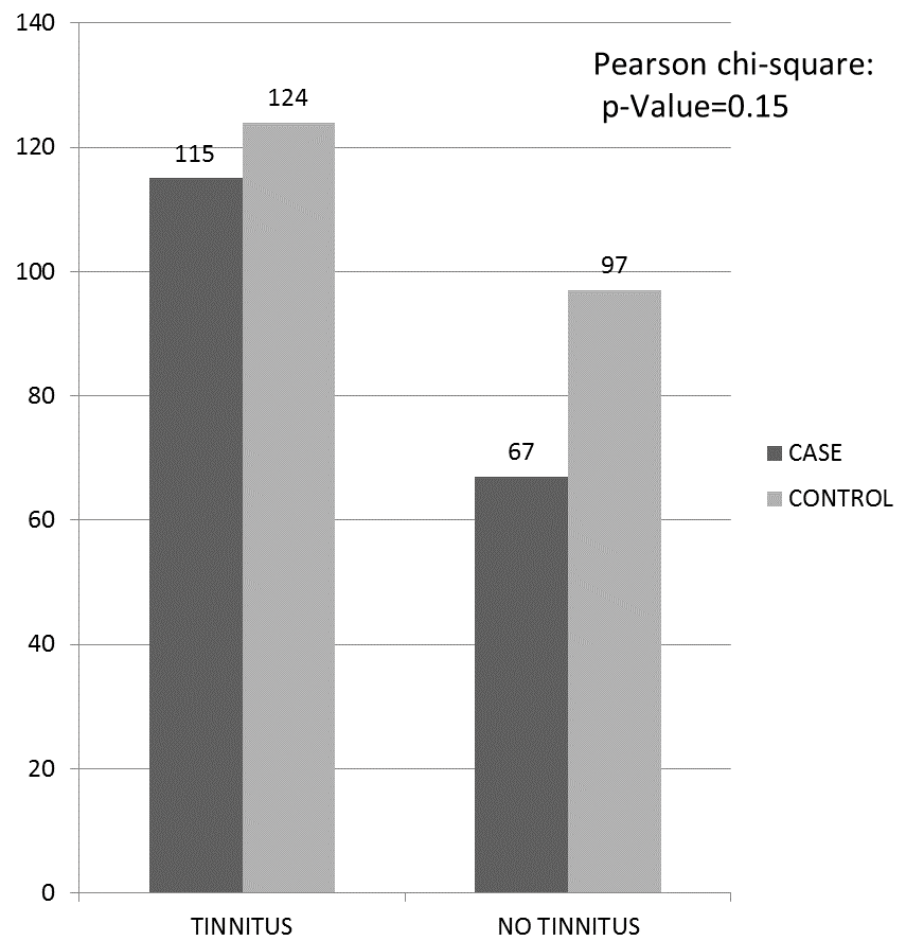

Figure 2. Incidence of tinnitus among cases and controls (182 cases and 221 controls).

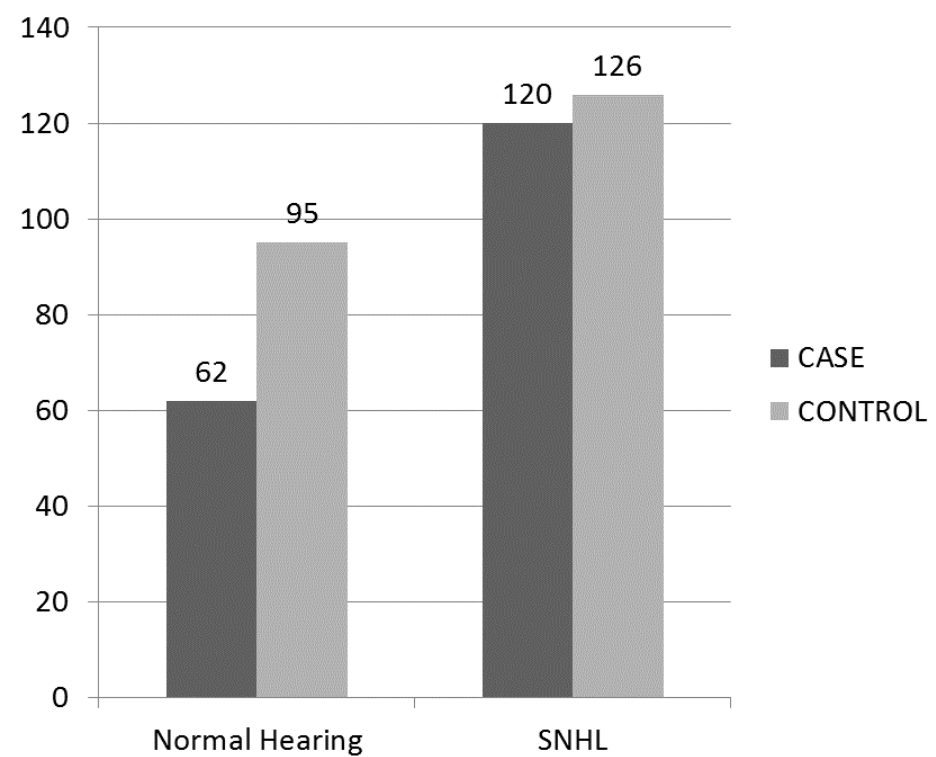

Figure 3. Incidence of sensorineural hearing loss among cases and controls (182 cases and 221 controls). 


\section{Percentage Distribution of Hearing Loss among Study Population and Controls}

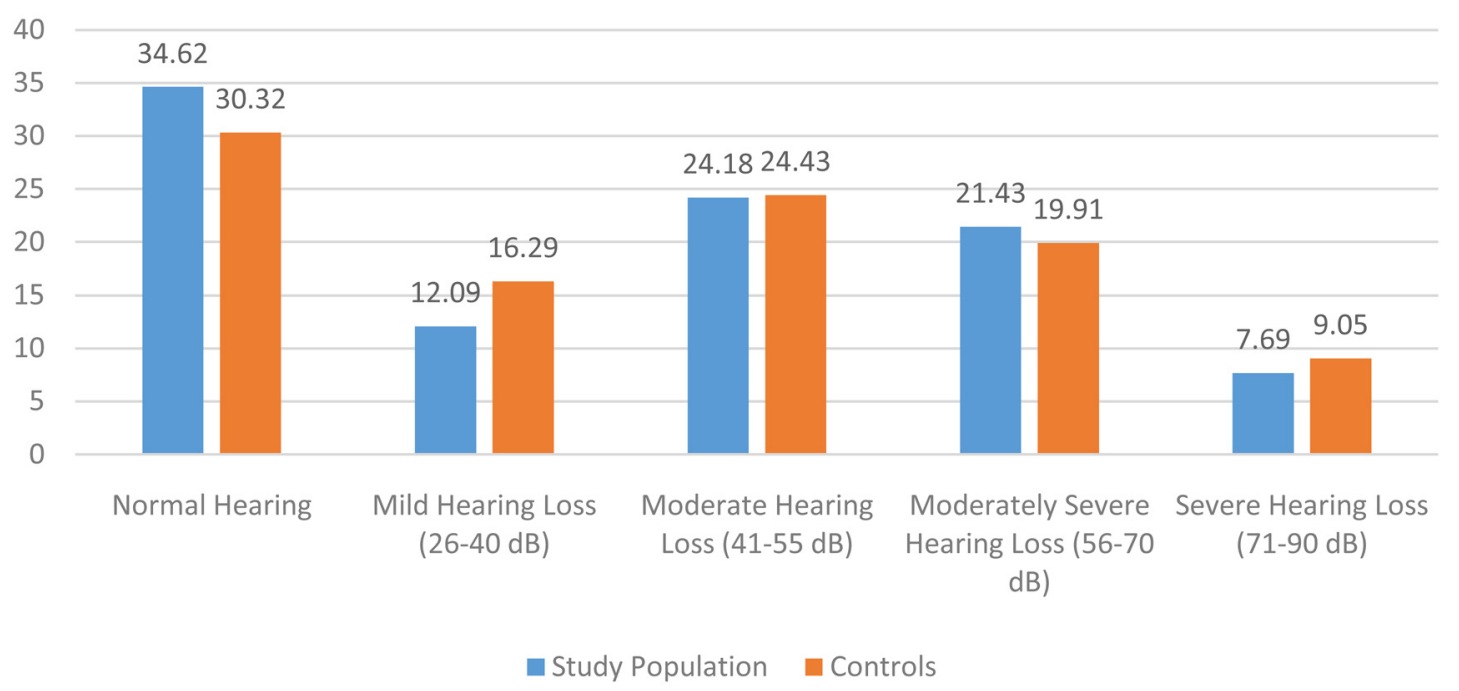

Figure 4. Percentage Distribution of Hearing Lossa Among Study Population and Controls.

p value of $20 \%$ or less in the bivariate analysis were then included for binary logistic regression analysis. The variables subjected to the model were age group, duration of aspirin use, hypertension and diabetes mellitus.

When logistic regression was applied among the study population it was found that age of the patient was most significantly associated with hearing loss. Patients aged 51-59 were 14.258 times more prone to develop hearing loss and patient aged 60-75 were 61.389 times more prone to develop hearing loss than patients aged less than 50 years of age (Table 2).

It was also found that only age of the study population was significantly associated with tinnitus. Duration of aspirin use, hypertension and diabetes were not found to be associated with tinnitus. People less than 50 years of age were 32.612 less likely to develop tinnitus than people between $60-75$ years of age. Similarly patients between 51-59 years of age were 2.799 times less likely to develop tinnitus than people aged between 60-75 years (Table 3 ).

Dataset 1. Raw data collected from the study population

http://dx.doi.org/10.5256/f1000research.11131.d156960
Dataset 2. Raw data collected from the control population

http://dx.doi.org/10.5256/f1000research.11131.d156961

\section{Discussion}

In the present study, the mean age of the patient was 63.7 years. As most patients on regular aspirin were above the age of 60 , aspirin was not seen as the principal cause of sensorineural hearing loss in our study. Logistic regression analysis demonstrated that- other factors like duration of aspirin intake, and other comorbidities like hypertension and diabetes were not found to produce any significant effect on the hearing status of the patient. Our results oppose Curhan et al's, which had shown that aspirin given for its anti-platelet effect in cardiovascular patients is responsible for causing hearing loss even in low doses. Hearing loss was seen as one of the complications of regular analgesic use. The risk was seen greatest among men below the age of 60 years. Above the age of 60 years, no relation was seen between hearing loss and aspirin use $\mathrm{e}^{4}$.

With increasing age, the prevalence of the hearing loss also increases $^{6}$. Studies have shown that after the age of 60 , hearing thresholds worsen on average by $1 \mathrm{~dB}$ per year, but the rate 


\begin{tabular}{|c|c|c|c|c|c|c|}
\hline & \multirow{2}{*}{ PARAMETERS } & \multirow{2}{*}{$\begin{array}{l}\text { STANDARD } \\
\text { ERROR }\end{array}$} & \multirow{2}{*}{ SIGNIFICANCE } & \multirow{2}{*}{$\begin{array}{c}\text { RISK } \\
\text { RATIO } \\
\text { (EXP B) }\end{array}$} & \multicolumn{2}{|c|}{$\begin{array}{l}\text { 95\% CONFIDENCE } \\
\text { INTERVAL FOR EXP(B) }\end{array}$} \\
\hline & & & & & $\begin{array}{l}\text { LOWER } \\
\text { BORDER }\end{array}$ & $\begin{array}{l}\text { UPPER } \\
\text { BORDER }\end{array}$ \\
\hline \multirow{8}{*}{ Step 1} & Age(<50yrs) & & $<0.001$ & & & \\
\hline & Age(51-59yrs) & 1.113 & 0.026 & 11.828 & 1.336 & 104.743 \\
\hline & Age(60-75yrs) & 1.105 & $<0.001$ & 49.277 & 5.649 & 429.860 \\
\hline & $\begin{array}{l}\text { Duration of aspirin } \\
\text { (1-4yrs) }\end{array}$ & & 0.285 & & & \\
\hline & $\begin{array}{l}\text { Duration of aspirin } \\
\text { (5-8yrs) }\end{array}$ & 0.388 & 0.212 & 1.624 & 0.759 & 3.473 \\
\hline & $\begin{array}{l}\text { Duration of aspirin } \\
\text { (>8yrs) }\end{array}$ & 0.690 & 0.176 & 2.544 & 0.658 & 9.843 \\
\hline & HTN(Yes) & 0.541 & 0.630 & 1.297 & 0.449 & 3.745 \\
\hline & DM(Yes) & 0.380 & 0.390 & 1.386 & 0.659 & 2.917 \\
\hline \multirow{7}{*}{ Step 2} & Age(<50yrs) & & $<0.001$ & & & \\
\hline & Age(51-59yrs) & 1.079 & 0.016 & 13.531 & 1.634 & 112.08 \\
\hline & Age(60-75yrs) & 1.080 & $<0.001$ & 55.477 & 6.686 & 460.299 \\
\hline & $\begin{array}{l}\text { Duration of aspirin } \\
\text { (1-4yrs) }\end{array}$ & & 0.29 & & & \\
\hline & $\begin{array}{l}\text { Duration of aspirin } \\
\text { (5-8yrs) }\end{array}$ & 0.387 & 0.203 & 1.636 & 0.766 & 3.494 \\
\hline & $\begin{array}{l}\text { Duration of aspirin } \\
\text { (>8yrs) }\end{array}$ & 0.688 & 0.187 & 2.478 & 0.643 & 9.547 \\
\hline & DM(Yes) & 0.359 & 0.453 & 1.310 & 0.648 & 2.648 \\
\hline \multirow{6}{*}{ Step 3} & Age(<50yrs) & & $<0.001$ & & & \\
\hline & Age(51-59yrs) & 1.077 & 0.013 & 14.379 & 1.741 & 118.783 \\
\hline & Age(60-75yrs) & 1.079 & $<0.001$ & 58.811 & 7.101 & 487.104 \\
\hline & $\begin{array}{l}\text { Duration of aspirin } \\
\text { (1-4yrs) }\end{array}$ & & 0.256 & & & \\
\hline & $\begin{array}{l}\text { Duration of aspirin } \\
\text { (5-8yrs) }\end{array}$ & 0.386 & 0.184 & 1.67 & 0.784 & 3.556 \\
\hline & $\begin{array}{l}\text { Duration of aspirin } \\
\text { (>8yrs) }\end{array}$ & 0.682 & 0.167 & 2.57 & 0.675 & 9.789 \\
\hline \multirow{3}{*}{ Step 4} & Age(<50yrs) & & 0.013 & & & \\
\hline & Age(51-59yrs) & 1.067 & $<0.001$ & 14.258 & 1.761 & 115.434 \\
\hline & Age(60-75yrs) & 1.070 & 0.013 & 61.389 & 7.543 & 499.591 \\
\hline
\end{tabular}



Table 3. Regression analysis of age, duration of aspirin intake, hypertension (HTN) and
diabetes (DM) with tinnitus (182 cases).

\begin{tabular}{|c|c|c|c|c|c|}
\hline \multirow{2}{*}{ PARAMETERS } & \multirow{2}{*}{$\begin{array}{l}\text { STANDARD } \\
\text { ERROR }\end{array}$} & \multirow{2}{*}{ SIGNIFICANCE } & \multirow{2}{*}{$\begin{array}{c}\text { RISK } \\
\text { RATIO } \\
\text { EXP (B) }\end{array}$} & \multicolumn{2}{|c|}{$\begin{array}{l}\text { 95\% CONFIDENCE } \\
\text { INTERVAL FOR EXP(B) }\end{array}$} \\
\hline & & & & $\begin{array}{l}\text { LOWER } \\
\text { BORDER }\end{array}$ & $\begin{array}{l}\text { UPPER } \\
\text { BORDER }\end{array}$ \\
\hline $\operatorname{Age}(<=50$ YRS $)$ & 0.826 & $<0.001$ & 32.612 & 6.465 & 164.499 \\
\hline Age(51-59 YRS) & 0.357 & 0.004 & 2.799 & 1.390 & 5.638 \\
\hline \multicolumn{6}{|l|}{ Age(60-75 YRS) } \\
\hline HTN(ABSENT) & 0.682 & 0.409 & 0.644 & 0.226 & 1.831 \\
\hline \multicolumn{6}{|l|}{ HTN(PRESENT) } \\
\hline DM(ABSENT) & 0.081 & 0.776 & 1.107 & 0.549 & 2.232 \\
\hline \multicolumn{6}{|l|}{ DM(PRESENT) } \\
\hline $\begin{array}{l}\text { DURATION OF } \\
\text { ASPIRIN(1-4 YRS) }\end{array}$ & 0.257 & 0.612 & 1.361 & 0.413 & 4.481 \\
\hline $\begin{array}{l}\text { DURATION OF } \\
\text { ASPIRIN(5-8 YRS) }\end{array}$ & 0.014 & 0.907 & 0.936 & 0.306 & 2.860 \\
\hline $\begin{array}{l}\text { DURATION OF } \\
\text { ASPIRIN(>8YRS) }\end{array}$ & & & & & \\
\hline
\end{tabular}

of decline of hearing loss may be even greater in men aged 48-59 years ${ }^{7,8}$. The relationship between regular use of aspirin and hearing loss was observed as strongest in men younger than 60 years of age. A possible explanation for this might be that after the age of 60 the cumulative effects of age and other comorbidities will add up in the causation of hearing loss. Bainbridge et al showed similar impact of age and diabetes on hearing loss .

High doses of salicylates can have ototoxic effects which include reversible hearing loss and tinnitus. Animal models have shown that salicylate is responsible for abnormal function of the outer hair cell and decreased blood flow in the cochlea ${ }^{3}$. Membrane conductance of the outer hair cell changes because of biochemical and electrophysiological alteration induced by salicylates. Salicylates also cause auditory microvasculature vasoconstriction, most probably caused by their antiprostaglandin activity $^{10,11}$.

Histopathologic studies of human temporal bones and animals on salicylate administration show degeneration of the strial microvasculature ${ }^{12,13}$. Microvascular vasoconstriction leads to strial degeneration. However, strial vascularis degeneration is also one of the characteristic features of age-related hearing loss ${ }^{14}$. Animal studies have shown that strial degeneration leads to its atrophy and to capillary loss, with basement membrane thickening and deposition of laminin and immunoglobulin in the strial vasculature ${ }^{15-17}$.

Inflammatory mediators like TNF- $\alpha$ affects microvascular tone, thereby reducing cochlear blood flow ${ }^{18}$. Other inflammatory biomarkers like white blood cell count, neutrophil count, IL-6 and CRP are associated with hearing loss in older people ${ }^{19}$. Over a 10 year period, older people with higher levels of CRP were two times more likely to develop hearing loss than normal ${ }^{20}$. Aspirin inhibits platelet enzyme cyclo-oxygenase (COX). Increased expression of genes for IL- $1 \beta$, IL- 6 , TNF- $\alpha$, and COX- 2 occurs during prostaglandin biosynthesis, and this effect is inhibited by aspirin ${ }^{21}$. Aspirin is also responsible for the synthesis of anti-inflammatory compounds called 'aspirin-triggered 15-epilipoxins'. This is responsible for the drug's anti-inflammatory effect even at low doses ${ }^{22}$. Aspirin also decreases chronic inflammatory biomarkers responsible for the aging process ${ }^{23}$. A randomized controlled trial where $100 \mathrm{mg}$ of aspirin was given for acute coronary syndrome showed decrease in the level of both CRP and TNF- $\alpha^{24}$. These studies show that that aspirin in low doses may have a protective effect on hearing instead of a deteriorating effect. Recently, a clinical trial is going on to see whether aspirin in low doses can decrease the progression of age-related hearing $\operatorname{loss}^{25}$.

This study has certain limitations. Aspirin in low dose is an over the counter medication and is used by a large proportion of the population. To find out whether aspirin is responsible for causing hearing loss or not, sample size needs to be huge, and the samples should be followed up for a long period of time. Because of time constraints, this was not possible for this study. Hearing evaluation before the patient began aspirin treatment was also not carried out. The lowest age group patient in this study was 34 years and patients below 50 years of age were very few in number so the first age group made was from 15-50 years. 


\section{Conclusions}

Hearing impairment is an important public health issue. Aspirin is one of the most common medications used now-a-days owing to the increased prevalence of cardiovascular diseases. The present study shows that long term use of aspirin doesn't cause any hearing loss. The relationship between long term use of low dose aspirin and hearing loss is still a debatable subject. Other factors like age of the patient, hypertension and diabetes mellitus must also be looked at if a person on aspirin develops symptoms of hearing loss.

\section{Data availability}

Dataset 1: Raw data collected from the study population.

DOI, 10.5256/f1000research.11131.d15696026

Dataset 2: Raw data collected from the control population. DOI, 10.5256/f1000research.11131.d15696127

\section{Author contributions}

The study was conducted at the B.P. Koirala Institute of Health Sciences, Dharan, Nepal. AP was responsible for the data collection and analysis, and for writing up the article. SB was responsible for the concept of the study and for monitoring its progress.

\section{Competing interests}

No competing interests were disclosed.

\section{Grant information}

The author(s) declared that no grants were involved in supporting this work.

\section{Acknowledgements}

We would like to acknowledge Dr. Pranil Pradhan for helping us with the statistics of this study.

\section{Supplementary material}

Supplementary File 1: A table showing air conduction and bone conduction threshold of study population across different frequencies.

Click here to access the data.

Supplementary File 2: A table showing air conduction and bone conduction threshold of controls across different frequencies.

Click here to access the data.

1. Omran AR: The epidemiologic transition: a theory of the epidemiology of population change. 1971. Milbank Q. 2005; 83(4): 731-57. PubMed Abstract | Publisher Full Text | Free Full Text

2. Anthony SF, Braunwald E, Kasper DL, et al.: Harrison's Principles of Internal Medicine. 16th Edition. New York: McGraw-Hill, Medical Pub. Division. 2008; $1514-1544$.

3. Jung TT, Rhee CK, Lee CS, et al: Ototoxicity of salicylate, nonsteroidal antiinflammatory drugs, and quinine. Otolaryngol Clin North Am. 1993; 26(5): 791-810.

PubMed Abstract

4. Curhan SG, Eavey R, Shargorodsky J, et al: Analgesic use and the risk of hearing loss in men. Am J Med. 2010; 123(3): 231-237. PubMed Abstract | Publisher Full Text | Free Full Text

5. Halla JT, Hardin JG: Salicylate ototoxicity in patients with rheumatoid arthritis: a controlled study. Ann Rheum Dis. 1988; 47(2): 134-137. PubMed Abstract | Publisher Full Text | Free Full Text

6. Cruickshanks KJ, Wiley TL, Tweed TS, et al.: Prevalence of hearing loss in olde adults in Beaver Dam Wisconsin. the epidemiology of hearing loss study. Am J Epidemiol. 1998; 148(9): 879-886. PubMed Abstract | Publisher Full Text

7. Lee FS, Matthews LJ, Dubno JR, et al.: Longitudinal study of pure-tone thresholds in older persons. Ear Hear. 2005; 26(1): 1-11. PubMed Abstract | Publisher Full Text

8. Wiley TL, Chappell R, Carmichael L, et al.: Changes in hearing thresholds over 10 years in older adults. J Am Acad Audiol. 2008; 19(4): 281-292, quiz 371. PubMed Abstract | Publisher Full Text | Free Full Text

9. Bainbridge KE, Hoffman HJ, Cowie CC: Diabetes and hearing impairment in the United States: audiometric evidence from the National Health and Nutrition
Examination Survey, 1999 to 2004. Ann Intern Med. 2008; 149(1): 1-10. PubMed Abstract | Publisher Full Text | Free Full Text

10. Stypulkowski PH: Mechanisms of salicylate ototoxicity. Hear Res. 1990; 46(1-2): 113-45.

PubMed Abstract | Publisher Full Text

11. Brien JA: Ototoxicity associated with salicylates. A brief review. Drug Saf. 1993; 9(2): 143-8.

PubMed Abstract | Publisher Full Text

12. Nelson EG, Hinojosa R: Presbycusis: a human temporal bone study of individuals with downward sloping audiometric patterns of hearing loss and review of the literature. Laryngoscope. 2006; 116(9 Pt 3 Suppl 112): 1-12. PubMed Abstract | Publisher Full Text

13. Gratton MA, Schulte BA: Alterations in microvasculature are associated with atrophy of the stria vascularis in quiet-aged gerbils. Hear Res. 1995; 82(1): 44-52. PubMed Abstract | Publisher Full Text

14. Spicer SS, Schulte BA: Spiral ligament pathology in quiet-aged gerbils. Hear Res. 2002; 172(1-2): 172-85. PubMed Abstract | Publisher Full Text

15. Ohlemiller KK: Mechanisms and genes in human strial presbycusis from animal models. Brain Res. 2009; 1277: 70-83.

PubMed Abstract | Publisher Full Text | Free Full Text

16. Gates GA, Mills JH: Presbycusis. Lancet. 2005; 366(9491): 1111-20. PubMed Abstract | Publisher Full Text

17. Sakaguchi N, Spicer SS, Thomopoulos GN, et al:: Immunoglobulin deposition in thickened basement membranes of aging strial capillaries. Hear Res. 1997; 109(1-2): 83-91.

PubMed Abstract | Publisher Full Text

18. Scherer EQ, Yang J, Canis M, et al:: Tumor necrosis factor- $\alpha$ enhances 
microvascular tone and reduces blood flow in the cochlea via enhanced sphingosine-1-phosphate signaling. Stroke. 2010; 41(11): 2618-2624. PubMed Abstract | Publisher Full Text | Free Full Text

19. Verschuur CA, Dowell A, Syddall HE, et al:: Markers of inflammatory status are associated with hearing threshold in older people: findings from the Hertfordshire Ageing Study. Age Ageing. 2012; 41(1): 92-97. PubMed Abstract | Publisher Full Text

20. Nash SD, Cruickshanks KJ, Klein R, et al.: Long-term variability of inflammatory markers and associated factors in a population-based cohort. J Am Geriatr Soc. 2013; 61(8): 1269-76.

PubMed Abstract | Publisher Full Text | Free Full Text

21. Chung HY, Cesari M, Anton S, et al.: Molecular inflammation: underpinnings of aging and age-related diseases. Ageing Res Rev. 2009; 8(1): 18-30.

PubMled Abstract | Publisher Full Text | Free Full Text

22. Brancaleone V, Gobbetti T, Cenac N, et al:: A vasculo-protective circuit centered on lipoxin $A_{4}$ and aspirin-triggered 15-epi-lipoxin $A_{4}$ operative in murine microcirculation. Blood. 2013; 122(4): 608-617.

PubMed Abstract | Publisher Full Text | Free Full Text
23. Singh $\mathrm{T}$, Newman AB: Inflammatory markers in population studies of aging Ageing Res Rev. 2011; 10(3): 319-29.

PubMed Abstract | Publisher Full Text | Free Full Tex

24. Chen $Y, X u F$, Zhang $Y$, et al:: Effect of aspirin plus clopidogrel on inflammatory markers in patients with non-ST-segment elevation acute coronary syndrome. Chin Med J (Engl). 2006; 119(1): 32-6. PubMed Abstract

25. Lowthian JA, Britt CJ, Rance G, et al:: Slowing the progression of age-related hearing loss: Rationale and study design of the ASPIRIN in HEARING, retinal vessels imaging and neurocognition in older generations (ASPREE-HEARING) trial. Contemp Clin Trials. 2016; 46: 60-66. PubMed Abstract | Publisher Full Text

26. Pokharel A, Bhandary S: Dataset 1 in: Evaluation of hearing level in patients on long term aspirin therapy. F1000Research. 2017. Data Source

27. Pokharel A, Bhandary S: Dataset 2 in: Evaluation of hearing level in patients on long term aspirin therapy. F1000Research. 2017. Data Source 


\section{Open Peer Review}

\section{Current Peer Review Status: ? $\checkmark$ ?}

\section{Version 2}

Reviewer Report 18 April 2018

https://doi.org/10.5256/f1000research.15247.r30913

(C) 2018 Storey E. This is an open access peer review report distributed under the terms of the Creative Commons Attribution License, which permits unrestricted use, distribution, and reproduction in any medium, provided the original work is properly cited.

\section{Elsdon Storey}

Department of Medicine (Neuroscience), Monash University, Melbourne, Vic, Australia

Competing Interests: No competing interests were disclosed.

I confirm that I have read this submission and believe that I have an appropriate level of expertise to confirm that it is of an acceptable scientific standard.

\section{Version 1}

Reviewer Report 19 May 2017

\section{https://doi.org/10.5256/f1000research.12008.r21660}

(C) 2017 Varghese A et al. This is an open access peer review report distributed under the terms of the Creative Commons Attribution License, which permits unrestricted use, distribution, and reproduction in any medium, provided the original work is properly cited.

\section{Ajoy Mathew Varghese \\ Department of Otolaryngology and Head and Neck Surgery, Christian Medical College, Vellore, India \\ Sheeja Susan John \\ Department of Ophthalmology, Christian Medical College, Vellore, India \\ Introduction \\ 1. Research question: The authors have aimed to look at the effect of prolonged use of low dose aspirin on hearing. The question is relevant as most of the previous studies on the subject have looked at the effect of high dose aspirin.}


2. Aim and objectives stated in abstract and introduction differ from the ones stated in the Methods section. These need to be stated clearly and consistently.

\section{Methods}

1. Study design: The authors have done a cross sectional comparative study between patients with cardiac disease on aspirin, and controls without cardiac disease and not on aspirin.

2. Controls cannot be termed 'healthy'. They were age-matched subjects without heart disease, and not on aspirin therapy.

3. If age matched controls were selected, why is there a difference in the number of cases and controls? Were there any drop outs from the study?

4. What were the criteria for diagnosing hearing loss? Since patients did not have a baseline audiological test, how were hearing loss and progression of hearing loss defined? Were questionnaires used? Where they standardized?

5. Systemic risk factors for hearing loss e.g. Diabetes mellitus, hypertension, and chronic kidney disease, also had to be ruled out.' (para 5 in Methods section) These factors were present both in cases and controls (see Datasets). These factors were not ruled out. They were noted as potential confounders in both groups, and addressed in the logistic regression analysis.

6. Chronic kidney disease has been mentioned along with diabetes and hypertension as a confounding factor in the beginning of the manuscript. However, there is no mention of chronic kidney disease in the rest of the manuscript and data sets, and it has not been addressed in the logistic regression model. Please clarify.

\section{Results}

1. Baseline demographic data should be put in a table to ensure clarity.

2. Please depict the tinnitus and hearing loss in cases and controls, with p-values, as tables.

3. CKD was not included as part of the logistic regression. Why not? Please clarify. The textual interpretation of this could also be better worded.

4. Audiometric data need to be added both in the data set and the results.

\section{Discussion}

1. The discussion needs to be clearer, more concise, and should proceed in a logical sequence. In the discussion, the authors should cite studies that have shown that aspirin could cause hearing loss, and how the current study differs from them, and possible reasons as to why. Then they should discuss studies and theories to the contrary, that agree with the results of the current study. This should be done in a logical and concise manner. Please avoid 
unnecessary and confusing details of various theories that have no direct implication on the subject of research.

2. The 'prevalence' of hearing loss in both cases and controls is far above the prevalence quoted in existing literature. Is there an explanation for this?

3. Please give reference number for Curhan et al's paper at the end of the first citation in the manuscript. (para 1 in discussion)

4. The comparison of the present study with Curhan et al's work is not very clear. Are the authors trying to imply that their results conflict with those of this work because the majority of their study population (both cases and controls) was above the age of 60 ? Please make this clear.

\section{Conclusion}

1. Conclusion should correspond with the aim and objectives of the study. The present study found no relationship between long term, low dose aspirin use and hearing loss. Moreover, the study did not find any correlation between hearing loss and systemic diseases; hence the last line in the conclusion is not supported by the results of the study, and therefore, may be deleted.

\section{General comments}

1. Correction of grammar needs to be done throughout the manuscript.

2. Terminology such as 'cases' and 'controls,' and 'incidence' and 'prevalence' has been used loosely and interchangeably. This is not acceptable.

On the whole, the paper addresses a relevant research question, and may be indexed after making the suggested corrections.

Is the work clearly and accurately presented and does it cite the current literature? Partly

Is the study design appropriate and is the work technically sound? Yes

Are sufficient details of methods and analysis provided to allow replication by others? Partly

If applicable, is the statistical analysis and its interpretation appropriate?

I cannot comment. A qualified statistician is required.

Are all the source data underlying the results available to ensure full reproducibility? Partly

Are the conclusions drawn adequately supported by the results? 
Partly

Competing Interests: No competing interests were disclosed.

We confirm that we have read this submission and believe that we have an appropriate level of expertise to confirm that it is of an acceptable scientific standard, however we have significant reservations, as outlined above.

Reviewer Report 08 May 2017

https://doi.org/10.5256/f1000research.12008.r22554

(C) 2017 Storey E. This is an open access peer review report distributed under the terms of the Creative Commons Attribution License, which permits unrestricted use, distribution, and reproduction in any medium, provided the original work is properly cited.

\section{Elsdon Storey}

Department of Medicine (Neuroscience), Monash University, Melbourne, Vic, Australia

\section{Introduction:}

It is well-known that large doses of aspirin may produce reversible tinnitus and hearing loss. The authors set out to test whether prolonged use of low dose aspirin for heart disease (presumably mostly ischaemic in nature) has a deleterious effect on hearing. Unfortunately, there are a number of problems with this study.

\section{Subjects:}

1. The authors are correct in their acknowledgement of vascular risk factors such as hypertension and diabetes for age-related hearing loss. (This age-related loss is presumably predominant in this study, judging from the increase in deafness by age group.) The design of the study does not allow ischaemic heart disease - itself also a risk factor for age-related hearing loss - to be accounted for, as all the aspirin-taking group were on aspirin for heart disease, whereas none of the control group had this risk factor. This confounding factor can only be addressed in a blinded, randomised prospective trial of aspirin in healthy individuals, as the authors acknowledge.

2. There is some confusion regarding the risk factors diabetes and hypertension in the manuscript.

a) What criteria were used for these diagnoses? Furthermore, were the subjects screened for these risk factors as part of the study, or was there reliance on medical record review or on patient self-description?

b) These risk factors "... had to be ruled out" (Methods, para 5, page 2), but these factors were included in the regression analysis (Results, para 7, page 3). Were those with hypertension and diabetes indeed excluded from the study? 
3. While there was adjustment for age and sex, other known risk factors for age-related hearing loss such as smoking and educational level (Stevens G, et al. 2013 1; Agrawal Y, et al. $2008^{2}$ ) were not reported. Were there any group differences in these factors?

4. The age range stratification (15-50; 51-59; 60-75) seem rather arbitrary and uneven. Were these divisions chosen to equalise numbers? The grouping of 15 year olds with 50 year olds seems inappropriate, and presumably the heart disease for which the 15 year olds were on aspirin was rather different. I think that the study would have been stronger with the exclusion of this paediatric group (presumably small). A histogram of the age distribution Methods: of subjects and controls by year of age (not age group) would be illuminating.

Figure 1: The definition of hearing impairment is unclear. Why was the WHO classification not used? This averages the loss in $\mathrm{dB}$ at 4 frequencies: $0.5,1,2$ and $4 \mathrm{kHz}$ in the better ear, with mild loss being diagnosed at $>25 \mathrm{~dB}$ and moderate at $>40 \mathrm{~dB}$. I presume that a dichotomous classification of hearing impairment was applied given that chi-squared tests were applied to the data, but the definition of hearing loss is not actually stated.

In a related matter, the results were documented as low, middle, high frequency loss (Methods, para 6, page 2), but this stratification is not subsequently referred to in the Results section.

Noise-related deafness was excluded on history ("careful history was taken to rule out noiseinduced hearing loss in each occupation" - Results, para 4, page 3). Was the presence of a prominent notch on PTA at $4 \mathrm{kHz}$ used to complement the history of noise exposure as a cause of exclusionary noise-related deafness? (Incidentally, this exclusionary statement should appear in Methods rather than Results.)

Conductive loss was excluded on clinical examination and tuning fork tests. Was there a reason that a bone-ear conduction gap on audiometry was not used to complement this exclusionary point?

\section{Results:}

The results are tabulated with inappropriate precision (often to 4 or 5 significant figures).

\section{Discussion:}

Age-related hearing impairment is presumably the major cause of deafness in this study, as the relative risks of the older age bands suggest. There is animal evidence for microvascular involvement in age-related hearing loss (Prazma J, et al. 199033; Shi X. 20114). There is evidence from humans linking inflammatory states to age-related hearing loss by correlation of markers of mild systemic inflammatory states (raised IL- 6 and CRP levels) with hearing loss (Verschuur C, et al. $2012{ }^{5}$ ). In other words, a reasonable hypothesis would be that low dose aspirin is actually protective against age-related hearing loss. In this context the study by Curhan et al. cited by the authors deserves further discussion. It found greater rates of hearing loss with prolonged regular use of aspirin, NSAIDs, and paracetamol (acetaminophen). There are two problems with that study, however: firstly, it relied on self-report of symptoms of deafness, with confirmation by a professional again self-reported. A second and potentially greater problem is confounding by 
indication, in that the reason for taking these medications in the first place (e.g. mild inflammatory state) may itself have been responsible for some or all of the hearing impairment.

\section{Conclusion:}

As it stands, this submission requires considerably more work to reach a suitable level. However, the primary data is presumably still available, and the submission could be re-written and reanalysed, perhaps along the lines suggested above, to improve its suitability.

A minor comment is that the English expression requires some revision, although it is largely understandable in its current form.

\section{References}

1. Stevens G, Flaxman S, Brunskill E, Mascarenhas $M$, et al.: Global and regional hearing impairment prevalence: an analysis of 42 studies in 29 countries. Eur J Public Health. 2013; 23 (1): 146-52 PubMed Abstract | Publisher Full Text

2. Agrawal Y, Platz EA, Niparko JK: Prevalence of hearing loss and differences by demographic characteristics among US adults: data from the National Health and Nutrition Examination Survey, 1999-2004.Arch Intern Med. 2008; 168 (14): 1522-30 PubMed Abstract | Publisher Full Text 3. Prazma J, Carrasco VN, Butler B, Waters G, et al.: Cochlear microcirculation in young and old gerbils.Arch Otolaryngol Head Neck Surg. 1990; 116 (8): 932-6 PubMed Abstract 4. Shi X: Physiopathology of the cochlear microcirculation.Hear Res. 2011; 282 (1-2): 10-24 PubMed Abstract | Publisher Full Text

5. Verschuur CA, Dowell A, Syddall HE, Ntani G, et al.: Markers of inflammatory status are associated with hearing threshold in older people: findings from the Hertfordshire Ageing Study. Age Ageing. 2012; 41 (1): 92-7 PubMed Abstract | Publisher Full Text

Is the work clearly and accurately presented and does it cite the current literature? Partly

Is the study design appropriate and is the work technically sound? Partly

Are sufficient details of methods and analysis provided to allow replication by others? No

If applicable, is the statistical analysis and its interpretation appropriate? Partly

Are all the source data underlying the results available to ensure full reproducibility? No

Are the conclusions drawn adequately supported by the results? Partly

Competing Interests: No competing interests were disclosed. 
Reviewer Expertise: Neurology, large drug trials in the elderly (including hearing/aspirin)

I confirm that I have read this submission and believe that I have an appropriate level of expertise to confirm that it is of an acceptable scientific standard, however I have significant reservations, as outlined above.

Author Response 13 May 2017

Apar Pokharel, College of Medical Sciences, Bharatpur, Chitwan, Nepal

Thank you for your review. There are few queries raised which I want to address.

1. The patients were all taken from the Department of Internal Medicine. There all patients are screened for blood sugar level and bood pressure. It is very difficult to find pateints with heart disease and having neither hypertension nor diabetes. So there were included in the study and the risk of hearing loss was calculated using regression analysis.

2. Smoking was taken into account for the hearing loss. To minimize its effect as a confounding factor, in the control group population, smokers were also included. Education level was not seen in the study as the range of age was very high i.e., 1565 years.

3. The age grouping was done as 15-50yrs, 51-59yrs, 60-75 yrs because, it is very difficult to get cases with heart diseases on aspirin therapy in age less than 50 years. This age classification is also similar to article by Sharon G. Curhan, MD called "Analgesic Use and the Risk of Hearing Loss in Men " published in Am J Med. 2010 March ; 123(3): 231-237.

4. Noise induced Hearing Loss was excluded from history taking as well as from pure tone audiogram findings.

Competing Interests: No competing interests were disclosed.

Reviewer Report 19 April 2017

https://doi.org/10.5256/f1000research.12008.r21658

(C) 2017 Sheppard A. This is an open access peer review report distributed under the terms of the Creative Commons Attribution License, which permits unrestricted use, distribution, and reproduction in any medium, provided the original work is properly cited.

\section{Adam M. Sheppard}

Center for Hearing and Deafness, State University of New York at Buffalo, Buffalo, NY, USA

There are typographic errors included a repeated word three lines into the abstract.

The author's state that pure tone audiometric evaluations were performed but do not include graphical data in the manuscript, nor do they indicate frequency specific thresholds in the raw 
data attached, only PTAs. Air conduction and bone conduction information needs to be included in order to ascertain the impact of standing hearing loss has on the included participants, especially since many occupations of participants included are readily exposed to noise such as farmers, labourers, and drivers. Furthermore, ototoxic events primarily initiate at ultra-high frequencies $>8$ $\mathrm{kHz}$, which was not even measured in the present study and can have significant impact on conclusions.

The use of tuning fork is not exactly clear if pure tone audiometry was performed. Unless pure tone audiometry was only performed on the "better hearing cochlea", in which case the authors should have performed these studies binaurally.

The studies included do not fully address the impact that salicylate may have on hearing capability. Animal models have shown that salicylate can impact not only DPOAEs but permanently damage spiral ganglion neurons as well. Which could result in recoverable DPOAE's and thresholds but have a permanent impact on word recognition capabilities. While these observations have been made with significantly higher dosage of salicylate, and may not be present at lower dosages, details should still be included in the manuscript.

There are many claims in the text which are written as though supported by research. While I believe the text included in the manuscript, proper references need to be included for readers. This event is widespread throughout the manuscript.

The authors claim their data opposes Curhan et al's research. While findings were different, they need to include the significant differences between the two studies, one primary difference being the number of participants. This is addressed as the limitation, but should be also be interpreted in regards to difference in study results with Curhan et al. Despite the lower number of participants in the present study, the participants were well controlled age and gender. However, the youngest age group is inappropriately large. Dramatic differences in hearing are expected between the ages of 15-50 and should not be included in the same group.

The definition of tinnitus in the text is incorrect. The authors reference a previous studies classification used in that research paradigm (performed in 1988), but is not generally accepted definition of tinnitus. This likely has resulted in the inaccurately inflated occurrence of tinnitus in used participants. Typically, tinnitus can be present in $\sim 15-20 \%$ of the general public, but the $\sim 63 \%$ reported in the control group in the present study is much higher than expected.

Overall, the findings of the study could potentially be of interest. However, significant changes need to be made with clarity of writing, appropriate citations, divulging specific raw data to include frequency specific air and bone conduction results, better classification of tinnitus and labeling of such in raw data, along with other methodological changes to specifically address the question at hand.

\section{Is the work clearly and accurately presented and does it cite the current literature?} Partly

\section{Is the study design appropriate and is the work technically sound?}

Partly 
Are sufficient details of methods and analysis provided to allow replication by others? Yes

If applicable, is the statistical analysis and its interpretation appropriate?

I cannot comment. A qualified statistician is required.

Are all the source data underlying the results available to ensure full reproducibility?

Yes

Are the conclusions drawn adequately supported by the results?

Partly

Competing Interests: No competing interests were disclosed.

I confirm that I have read this submission and believe that I have an appropriate level of expertise to confirm that it is of an acceptable scientific standard, however I have significant reservations, as outlined above.

Author Response 25 Apr 2017

Apar Pokharel, College of Medical Sciences, Bharatpur, Chitwan, Nepal

Thank you for reviewing my article.

I want to add few explanations for your review comments.

1. I have included noise induced hearing loss as my exclusion criteria. For ototoxic

medications, I have taken detailed history before recruiting the study population and have tried to exclude such patients.

2. PTA was done for both ears.

3. DPOAE was not done this facility is not available in my institution.

4. In my study the percentage of tinnitus has come higher, because both in my study population and control, I have included patients with comorbidities like DM, HTN which themselves are responsible for causing hearing loss.

Thanks for your review.

Competing Interests: No competing interest 
The benefits of publishing with F1000Research:

- Your article is published within days, with no editorial bias

- You can publish traditional articles, null/negative results, case reports, data notes and more

- The peer review process is transparent and collaborative

- Your article is indexed in PubMed after passing peer review

- Dedicated customer support at every stage

For pre-submission enquiries, contact research@f1000.com 